\title{
Only Dead Metaphors Can Be Resurrected: A Review of Jill Lepore's These Truths
}

\section{George Blaustein}

\section{(2) OpenEdition \\ Journals}

Electronic version

URL: https://journals.openedition.org/ejas/16087

DOI: 10.4000/ejas.16087

ISSN: 1991-9336

Publisher

European Association for American Studies

\section{Electronic reference}

George Blaustein, "Only Dead Metaphors Can Be Resurrected: A Review of Jill Lepore's These Truths", European journal of American studies [Online], 15-2 | 2020, Online since 30 June 2020, connection on 08 July 2021. URL: http://journals.openedition.org/ejas/16087 ; DOl: https://doi.org/10.4000/ejas.16087

This text was automatically generated on 8 July 2021 .

Creative Commons License 


\title{
Only Dead Metaphors Can Be Resurrected: A Review of Jill Lepore's These Truths
}

\author{
George Blaustein
}

1 Historical narratives of the United States have never not been shaped by an anxiety about the end of it all. Will we, in the end, sink or soar? Are we a new Rome or a new Zion? Even the driest textbook turns lofty on its final page. Nor have such narratives ever been without a corresponding civic intention, stated or unstated: the point is to push the ending back awhile, to ensure a futurity for the American experiment, to endure.

2 Most textbooks push that ending back by returning, in those final pages that few students ever read, to founding principles-to the truths expressed in the Declaration of Independence, say, or in the Constitution's preamble-and concluding with the hope that American reality will one day meet them. If the historian is committed to democracy, as most textbook writers are, then the agents of history are presumed to be "the people." We the people need a national history because, after all, America still exists, and the course of our history will depend, tautologically, on us-the same us that is also, in theory, history's readers. The textbook, like the jeremiad, recalls founding ideals and chastises the present for not living up to them. As Sacvan Bercovitch argued, both the Jeremiah doing the yelling and the listeners doing the hearing are already in on the rhetoric. We know, implicitly, that the yelling lets us carry on. ${ }^{1}$

3 It is intriguing to imagine a narrative that altogether relinquishes this generic civic obligation. It could be structured around a frank acknowledgement of American decay. Perhaps write of America not as something "great" but as something small, tawdry, and provisional. Admit that the Constitution is a terrible scripture. Give up on newness and jump straight to American age. Or write American history as if from thousands of years in the future. Mark Twain played this melancholy game while touring ruins in Europe and the Holy Land, in 1867, two years after the Civil War. The ruins made him wonder, 
"What may be left of General Grant's great name forty centuries hence?" So he conjured this helpful entry from an "Encyclopedia for A.D. 5868":

URIAH S. (or Z.) GRAUNT-popular poet of ancient times in the Aztec provinces of the United States of British America. Some authors say flourished about A.D. 742; but the learned Ah-ah Foo-foo states that he was a contemporary of Scharkspyre, the English poet, and flourished about A.D. 1328, some three centuries after the Trojan war instead of before it. He wrote "Rock me to Sleep, Mother."

My favorite detail is the deadpan clarification that "Graunt" flourished "some three centuries after the Trojan war instead of before it"-a glimmer of what else one would learn from this future Encyclopedia of error and inversion. ${ }^{2}$

5 But we are all condemned to live in the present, and the present seems like an apocalyptic moment for the American historical narrative, at least of the textbook variety. A unique national future cannot be presumed, and not only because a future in general cannot be presumed. The veil has been drawn back: the history of the United States is cut from the same cloth as everything else. It is dismal to admit that American history is continuous with history's general "panorama of sin and suffering." That was Hegel's phrase for the basic human experience of worldly time, before the historian steps in to lift a narrative out of it. ${ }^{3}$

These Truths: A History of the United States is the eleventh of the prolific historian Jill Lepore's twelve books, a number that includes one co-authored work of historical fiction. This one is her most ambitious. It is also a throwback to an older genre: the national history. "I wrote this book," she writes with candor and caveat, "because writing an American history from beginning to end and across that divide hasn't been attempted in a long time, and it's important, and it seemed worth a try." ${ }^{4}$ It is worth a try! And These Truths may take its place as a standard history, partly because of its pedigree-Harvard and the New Yorker-and partly because of its elegance and digestibility.

8 It is not entirely true that such an American history "hasn't been attempted in a long time," but as a textbook, or textbookish antidote to textbooks, the book is notable for making its civic purpose explicit rather than implicit, and for its more direct acknowledgment of political urgency. "The United States is founded on a set of ideas," Lepore writes, "but Americans have become so divided that they no longer agree, if they ever did, about what those ideas are, or were." So These Truths is "meant to double as an old-fashioned civics book, an explanation of the origins and ends of democratic institutions, from the town meeting to the party system, from the nominating convention to the secret ballot, from talk radio to Internet polls" (xviii-xix). The book's outermost frame is a yes-or-no question: "Can a political society really be governed by reflection and election, by reason and truth, rather than by accident and violence, by prejudice and deceit?" (xiv). This is a loaded question, the only acceptable answers being yes, maybe, and I hope so. (In fact These Truths will arrive, maybe despite itself, at a remarkably bleak assessment of present-day national political resources.) The book's real task is to demonstrate that history, when animated in a particular way, can lift us toward a humane or enlightened politics. Read me, it whispers, and you will be equipped to steer the ship of state through the storm.

9 It is no easy thing, nowadays, to tell an inspiriting national history. Lepore's attempt has received admiring reviews and critical reviews. The criticisms are usually about 
what is muted or left out-voices, regions, whole methodologies and historical processes. For Christine DeLucia, the core flaw is methodological: Lepore's exclusive "reliance on written literacy and record-keeping as powerful determinants of history and memory" blinds her to indigenous historiography and to "non-textual knowledge systems and cross-cultural translation," and leaves the book without fully-rendered indigenous voices. For Richard White, the flaws are methodological as well as stylistic. Lepore's inattention to political economy as a decisive factor in history makes her account cursory and superficial, especially of the Gilded Age and the histories of the West and Midwest. The style of the book, meanwhile, crystallizes a lamentable "New Yorkerization of American history." 5

10 My concern here is not the book's exclusions, exactly, nor its more-or-less familiar ideological project. By now, most respectable college-level textbooks already have the same liberal-progressive oomph, and the same aspiration toward enlightened consensus. What is remarkable about These Truths is its storytelling, the structure it grafts onto the past, its attempt to revive national history as a serious genre-in other words, its narrative form. It represents the pinnacle of contemporary liberal nationalist history-writing. If we seek an anatomy of that historiography, and if we want to know its limits, These Truths is a good place to look. It is an occasion to ask what national history is, and what it is for.

I.

11 Historical narratives need a beginning, and These Truths begins, as it must, with conquest and catastrophe. "We saw naked people," Columbus wrote in his diary, describing the Taíno people on the island he called Hispaniola. The Taíno, Lepore notes, had no writing; "they sang their laws, and they sang their history." The context is soon saturated by colonization, slaughter, and disease. "There were about three million people on that island ... when Columbus landed; fifty years later, there were only five hundred; everyone else had died, their songs unsung."

12 So begins Part I, “THE IDEA, 1492-1799." It starts with European colonization and will arrive at revolution and the national founding. A book like this cannot convey the fullness of colonial devastation, but only gesture with solemnity toward the exponential horror. "Meanwhile, the people of the New World: they died by the hundreds, they died by the thousands, by the tens of thousands, by the hundreds of thousands, by the tens of millions." English and French colonization followed Spanish and Portuguese; Lepore invokes the 17th-century English vicar Samuel Purchas, whose history of the world suggested that Europeans' "literall advantage" explained their colonial dominance in America (13). Literacy itself, in other words, enters the narrative as one more tool of subjection. The legal and historical foundations of what will become the United States lie here, in slavery above all. "In one of the more unsettling ironies of American history," Lepore writes of colonial Virginia, "laws drafted to justify slavery and to govern slaves also codified new ideas about liberty and the government of the free" (48). There is nary an American branch without that root.

13 The workings of oppression nevertheless give way, over three centuries, to revolution and, by the end of the period, to an antislavery impulse that has become its own moral force in history. By the 1780s the institution of slavery "had begun to break, like a plane of glass streaked with cracks but not yet shattered" (105). This progression from 
the darkness of point A to the promise of point B hinges on a central claim: "long before American independence was thought of, or even thinkable, a revolutionary tradition was forged, not by the English in America, but by Indians waging wars and slaves waging rebellions. They revolted again and again and again. Their revolutions came in waves that lashed the land" (55). Most of these revolutions were unrealized in their own era and aren't detailed in Lepore's account. But proleptic revolution is always present, as an ambient potential. One proof of that potential is the fact that European colonies had to operate, in effect, as massive counterinsurgency regimes.

14 With that origin of a revolutionary tradition in place, what we call "the American Revolution" thus becomes a white man's pale borrowing from it, an etiolated version of more radical uprisings and insurgencies. After slave rebellions rocked New York in the 1730 s and 1740s, white colonists in turn rebelled against the royal government, but they did so only in order to defend the racial order. "One kind of rebellion was celebrated, the other suppressed-a division that would endure," Lepore writes. "In American history, the relationship between liberty and slavery is at once deep and dark: the threat of black rebellion gave license to white political opposition" (64). ${ }^{6}$ White Virginians, meanwhile, articulated abstract rights in order to defend their nonabstract prerogatives as slaveowners. "Inevitably, slavery cast its long and terrible shadow over these statements of principle," Lepore writes of the 1776 Virginia Declaration of Rights and Form of Government, whose author, George Mason, owned slaves; "slavery, in fact, had made those statements of principle possible" (96). That the American Revolution was in fact such a borrowing would not have been clear to Thomas Jefferson, but it can be clear to us.

15 Call it a morally absurd irony, a contradiction, a paradox, a crime-it has been central to serious American historiography for decades. ${ }^{7}$ The Revolution would not have happened as it did, the Constitution would not have emerged as it did, without the political economy of slavery there as a precondition and to some degree a cause. Jefferson's ideas depended on enslaved labor, insofar as slavery made possible his freedom to have ideas at all. These Truths does not have to re-grapple with such questions in any sustained analytical way, because the predicament itself can be conveyed with the show-don't-tell sharpness of anecdote: James Madison, author of the Constitution, buys a copy of Leviathan in 1782, the same moment he was "short of cash and complaining that he would soon be "under the necessity of selling a negro"' (106).

16 But These Truths is a national history, and it has to draw at least some inspiration from the founding. The irony must be transcended. Positing a broader "revolutionary tradition" that emerged organically out of the histories of colonization and slavery-a tradition forged "by Indians waging wars and slaves waging rebellions"-lets Lepore fold even the American Revolution, with all its irony and hypocrisy, into a nobler story. "The American political tradition was forged by philosophers and by statesmen, by printers and by writers, and it was forged, too, by slaves" (64). The narrative of Part Iand thus the founding of the United States-can encompass, that is to say, the revolutions that were realized and the ones that were not. The reader can hold aloft THE IDEA, because THE IDEA is many things: reason, revolution, independence, emancipation, enlightened self-government, a new beginning. History can begin in chaotic and catastrophic darkness, but ideas can rise above the circumstances of their creation. 
17 The IDEA will not be fully achieved in the national founding; genuine consummation must remain in the future if the rest of the book is to be necessary and interesting. But the wished-for-ness of it makes the narrative all the more thrilling. The Declaration of Independence can now be "a stunning rhetorical feat, an act of extraordinary political courage" (97), even after we know its contradictory origins. The brilliance of the Constitution can outshine the grayness or villainy of its authors and assume mythic proportions: the "giant W" of "We the People" is "as sharp as a bird's claw" (xi). Historical events can now be page-turningly suspenseful: "Ratification proved to be a nail-biter" (128). The era's more radical potentialities, meanwhile, are also given vivid narration; they convey a parallel thrill of expectation. Those as-yet-unrealized revolutions can be incorporated, narratively if not historically, into the national aspiration. The "unsettling ironies" of the political prehistory of the United States-the articulations of liberty that depended on slavery-are re-settled into a more open, a more sprawling, and a more heroic plot.

18 Heroism itself-individual heroism and moral heroism-has become possible in a way that it was not possible before. As Part I arrives at the actual founding of the United States, its focus falls on family dramas. The latter parts of the book do not. Historical figures who lived in the shadow of the familiar founders are given the spotlightBenjamin Franklin's sister Jane, for instance. Jane's story conveys the social-historical fact that "girls, like slaves, were hardly ever taught to write (they were, however, taught to read, so that they could read the Bible)"; Jane's story also imparts a retrospective grandeur to a formerly-unrecognized individual (59). ${ }^{8}$ The familiar story of George Washington is juxtaposed with the parallel quests of Harry Washington, "who had once been Washington's property." Harry escaped from Mount Vernon to the British side during the revolution, made his way to Sierra Leone, "another unruly republic," and eventually led a rebellion there (147-148). The American founding needs Founders; the ingenuity of Lepore's storytelling is to make Harry Washington a Founder, too. There becomes part of the here.

Part I casts the national founding and its colonial prehistory into a particular narrative form. The narrative runs, in effect, on two tracks. One is the grisly epic of colonization, an epic that "raged on," as epics do, one crime after another (34). The other track is the emergence, over three centuries, of a moral sense that can rise above it. Part I, in other words, narrates not only the era's cruelties and contradictions, but also the emergence of our own capacity to recognize them as cruelties and contradictions at all.

This is an effective way of pulling a redemptive national founding from an otherwise unredeemable past. It acknowledges history's fundamental atrocities but rescues us, in the end, from those fundaments. As a narrative, it adheres to the archetypal plot structure that the historian and theorist Hayden White called a Romance, in his classic study of historiography, Metahistory: The Historical Imagination in Nineteenth-Century Europe. "The Romance," White wrote, "is fundamentally a drama of self-identification symbolized by the hero's transcendence of the world of experience, his victory over it, and his final liberation from it." The hero in this case is "the IDEA," and the array of enlightened or emancipatory things contained within it. The Romance "is a drama of the triumph of good over evil, of virtue over vice, of light over darkness, and of the ultimate transcendence of man over the world in which he was imprisoned by the Fall." Plotting the national founding this way is as much a literary act as it is, strictly 
speaking, a historical one. It is not the kind of thing one can simply call true or false, although one can certainly argue with it. The emplotment, to use White's term, is an act of narrative, a derivation of meaning and drama from the past's warp and woof.

The colonial prehistory can begin as a chronicle of devastation but become, ultimately, a triumph of light. This romantic frame, with its redemptive ending, makes it possible to approach so terrible a history with something like wonder. It is, after all, marvelous that Harry Washington would so perfectly echo George Washington's pro-slavery revolution with an anti-slavery revolution in Sierra Leone. That the historical record provides such improbably vivid stories-that the national founding can be emplotted as a Romance at all-is a marvel unto itself, with hints of providential design. None of it had to be; chaos did not have to yield to light. Romantic history allows for accidents and miracles. The word "America" was the coinage of a couple mapmakers who happened to read Amerigo Vespucci's account of the New World in 1507. "The name stuck by the merest accident," Lepore writes, while "much else did not last." By the 18th century, "a word on a long-ago map had swelled into an idea."

Hayden White died in 2018; Metahistory appeared in 1973. His main premise was that history is more art than science, that a historical text is, first and finally, a literary artifact. This premise was not the bland observation that historians are "biased"; it was a suggestion about the deeper cognitive and aesthetic structures of historical narrative itself. Any work of history emerges from the alchemy of a historian's expectations or longings, their self-awareness or inner blindness, their prefiguration of past events, their interrogated or uninterrogated theories of how the world's gears turn, their narrative license. There would be no history without that alchemy, no history without that narrative imagination. Moreover, we can only approach historical narrative with language, itself an imperfect (and therefore artful) way of apprehending the world. Good history is good not because it denies these workings of the imagination; it is good because of them.

24 The vocabulary of Metahistory is well-suited to the task at hand, for These Truths is a conspicuously emplotted book. One can see affinities, for instance, between Lepore and the 19th-century historian Jules Michelet, who emplotted the French Revolution as a Romance and whose books were similarly vivid. Michelet, White suggests, "conceived his task as a historian to be that of the custodian of the dead, whether they be conceived as good or evil by him, though in the interest finally of serving that justice in which the good are finally liberated from the 'prison' of human forgetfulness by the historian himself." ${ }^{10}$ Lepore would likewise bring the vividness of Romantic quest even to those who were crushed or silenced in their own era, precisely because her own historical writing has exhumed them and given them life. As a historian, she is both the custodian of what was, and the deliverer of the Romantic might-have-been.

25 There are in fact four grand plots in These Truths, one for each of the book's four chronological parts-a Romance, a Tragedy, a Comedy, and a Satire-each with their own implications for the workings of historical change. Within each plot are many voices, contrary moods and episodes, and sub-plottings, which might run counter to the grander arcs, adding tension and pathos to the drama, and thus making the grander arcs all the richer. The four broad emplotments determine what kind of heroism is possible in the world and era being narrated, or whether heroism is possible at all.

26 Lepore's work is marked less by a coherent philosophy of history than by a commitment to storytelling. This can read as mystifying or precious, as when she 
describes history as a method: "The work of the historian is not the work of the critic or of the moralist," she writes in the prologue, "it is the work of the sleuth and the storyteller, the philosopher and the scientist, the keeper of tales, the sayer of sooth, the teller of truth." As often happens in a Lepore sentence, the flourish and the treacle pile up and topple. But it is remarkable-poignant even-that into the vacuum of our moment, when the familiar center of the US history textbook no longer holds, there would come a book like this, harkening back to the historical imagination of earlier eras, and throwing everything and the kitchen sink at the problem of national history.

\section{II.}

27 Part II of These Truths is about "THE PEOPLE, 1800-1865." Emplotting this period as a Tragedy would seem like a more straightforward task than the problem of pulling a Romance from the history of colonization. "The United States was born as a republic and grew into a democracy," Lepore writes, "and, as it did, it split in two, unable to reconcile its system of government with the institution of slavery" (191). Part II chronicles territorial expansion and Indian removal, the market revolution and the dawn of "a distinctively American idea of progress," the political crisis of the 1850s, and finally the Civil War (191). The United States' first major national historian, George Bancroft, enters the drama as something of a prototype for Lepore herself. In 1826, Bancroft proclaimed that "The popular voice is all powerful with us; this is our oracle; this, we acknowledge is the voice of God," and he embarked on a massive, multivolume History of the United States in the age of Andrew Jackson. ${ }^{11}$ But he was fated to write Romantic histories in an era that Lepore emplots as Tragic. Bancroft could not see America as "a nation looking down the barrel of its own gun" (238).

Blindness is a recurring metaphor. THE PEOPLE believe that progress is inevitable, that destiny is manifest. But they cannot see, until it is too late, that cathartic cataclysm is also inevitable. Historical figures who played a part in the Romance here become tragic heroes. When Thomas Jefferson dies in 1826, Sally Hemings takes "a pair of Jefferson's eyeglasses to remember him by-a man of sight, a man of blindness" (186). References to Greek tragedy are explicit. In the wake of the Dred Scott case (1857), in which the Supreme Court declared that blacks could never be citizens, Lepore has Frederick Douglass look on in despair at the tragic hastening of contradictions: "it was as if the nation, like Oedipus of Thebes, had seen that in its own origins lay a curse, and had gouged out its own eyes" (271). Douglass is both an actor in the drama and its chorus. Henry Wadsworth Longfellow-a surrogate narrator, and a mark of the book's poetic as opposed to historical aspirations-noted in his diary that "the dissolution of the Union goes slowly on ... Behind it all I hear the low murmur of the slaves, like the chorus in a Greek tragedy" (301).

29 The Civil War is the Tragedy's agon, the scene of suffering. It marks, in White's terms, "the fall of the protagonist and the shaking of the world he inhabits," but Tragedy brings "a gain in consciousness for the spectators of the contest. And this gain is thought to consist in the epiphany of the law governing human existence which the protagonist's exertions against the world have brought to pass." ${ }^{12}$ Out of the Civil War comes Lepore's war-weary Abraham Lincoln, his face "sunken and craggy, as chiseled as a sea-swept rock." As he rises to deliver the Second Inaugural Address, "the skies cleared and the sun broke through the clouds" (304). 
30 Lincoln himself, in the Second Inaugural Address, emplotted the Civil War in tragic terms: "All dreaded it, all sought to avert it," he observed, and all knew that the slaveholding interest was "somehow the cause of the war." The conflict had its own inexorable logic, producing a result-the "fundamental and astounding" end of slavery -that neither side, in its partial blindness, could see beforehand. "Neither anticipated that the cause of the conflict might cease with or even before the conflict itself should cease." Narrating the war this way gave it meaning in 1865 , as it came to an end. The gain in consciousness for Lincoln and his listeners was theological and ideological: Lincoln articulated the theological epiphany that "the Almighty has his own purposes," and heralded the ideological triumph of free labor over the now-purged evil of slavery. 13

31 The emplotment in These Truths is similar to Lincoln's own: the tragic conflict is between sections, or between different visions of progress, or between slavery and freedom. Ironically, this is problem for Lepore's narrative, because Lincoln has already stated the moral of the story, which makes Part II's denouement more summary than history. History, after all, needs retrospect. Tragedy delivered a gain in consciousness to Lincoln's listeners, but the gain in consciousness that it is supposed to deliver to us, history's readers, is redundant or at best uncanny. American readers already have the sense that the war was "tragic"-it is there in advance, like a movie we've seen.

32 As an alternative, one might position, say, capitalism and democracy as the forces standing in inexorable conflict. Another theorist of history from the period, Karl Marx, defined the bourgeoisie by that more robustly tragic self-contradiction: the bourgeoisie, according to the Communist Manifesto, cannot exist "without constantly revolutionizing the instruments of production, and thereby the relations of productions, and with them the whole relations of society," which would lead dialectically to its demise. (Marx, it so happens, wrote rapturously about Lincoln and the Emancipation Proclamation, and he celebrated Lincoln as a bourgeois figure "sui generis in the annals of history." At the same time, he prophesied the bourgeoisie's selfdestruction, emplotting the bourgeoisie's Tragedy within the broader historical Comedy of the proletariat's emergence..$^{14}$ ) Lepore's account of the mid-19th century tends to downplay these internal structural contradictions. It emphasizes the more straightforward villainies of political violence and territorial expansion, and the novel cacophony of the era's news media, but it is not a decisively tragic account of political economy. The capitalism of that era, in fact, reads as more humane than our era's version, for instance forgiving debts in ways our society no longer does. "A nation of debtors, Americans came to see that most people who fall into debt are victims of the business cycle and not the fate of divine retribution or the wheel of fortune" (226). This looser narration is more about how "Americans" saw things than about the things that structured their seeing. It might stir a nostalgia for a kinder, gentler free labor ideology.

"As if the nation had gouged out its own eyes," Lepore writes-the as if hints that Part II is not a complete Tragedy but a near-Tragedy or pseudo-Tragedy. (In tropological terms, White would say it operates by simile rather than by a more decisive metonymy.) Narrator and reader enter the drama already looking for things that will be salvaged from the wreck. A vague spirit of democracy is salvaged even as we lament what the tragically-flawed democracy tragically did to itself. What the democracy did to others is 
attended to, certainly, but it is not an essential element of the consciousness gained in the denouement.

It is instructive to read These Truths alongside An Indigenous People's History of the United States, by Roxanne Dunbar-Ortiz, which appeared in 2014. Like These Truths, it announces itself as a corrective to the standard story, though where Lepore's corrective takes the form of liberal reconciliation, Dunbar-Ortiz's is blistering. Both are, so to speak, post-revisionist narratives, though from opposite directions. An Indigenous People's History is an emphatically anti-national textbook: by design, it defies incorporation into any liberal American narrative, however demographically capacious that narrative may be. It is pitched against "post-civil-rights-movement US history revisionism"-that is, against the now-diversified historical canon, with its noble black heroes and its "nation of immigrants." It reveals the palliative veneer of "multiculturalism" to be "an insidious smoke screen meant to obscure the fact that the very existence of the country is a result of the looting of an entire continent and its resources," merely the last insult heaped on the injury of colonization and genocide: "With multiculturalism, manifest destiny won the day." ${ }^{15}$ These books are narratively irreconcilable, even at those moments when they range over similar territories of dispossession. Books in the tradition of Howard Zinn's People's History of the United States, like Dunbar-Ortiz's, do not have the structure of Tragedy or any other emplotment; they have the structure of a trial. As narratives, they appeal to a legal and moral authority that stands above the scene of the crime, as it were, and they pronounce a verdict.

35 In These Truths, certain kinds of art and certain kinds of technology, certain democratic expressions and certain technological inventions, can be celebrated, insulated from Tragedy, even if the era tips inexorably toward the Civil War. Photography, for instance: "A photograph stops time, trapping it like a butterfly in a jar," Lepore similizes. "No other kind of historical evidence has this quality of instantaneity, of an impression taken in a moment, in a flicker, an eye opened and then shut." Whitman thought "all art will be democratized" by photographs, and Frederick Douglass loved to pose for them. Photographs are democratic insofar as they "capture the ordinary, the humble, the speechless," insofar as they don't discriminate "between the rich and the poor, the literature and the illiterate, the noisy and the quiet" (273). Maybe. This is no longer romance, but it is not quite tragedy.

36 Lepore is also fond of Henry David Thoreau, who found in Walden Pond just the right angle from which to watch the train of industrialization go by. "Thoreau's experiment wasn't a business; it was an antibusiness; he paid attention to what things cost because he tried never to buy anything." Thoreau withdraws from the democratic wreck in order to preserve a liberal national narrative for future Lepores. Walden is read as if it was written deliberately for us, the national us: a message of calm and narrative continuity in a transhistorical bottle, an organic jam to be opened and savored in the ignobly mechanized era that will close the book. The pastoral is thus shielded from economic determinism. This is what is meant by Lepore's otherwise curious line, "Instead of Marx, America had Thoreau" (231). Thoreau can emerge, in his own time and in ours, as a gardener in the machine. 
III. her favorite ideologue, who called for a "Composite Nationality" in 1869. (This is also the centerpiece of Lepore's subsequent programmatic essay, This America: The Case for the Nation. ${ }^{17}$ ) Douglass's vision failed in his own time, but Part III will arrive at a partial achievement of it. Emplotted as a Comedy, Part III arcs toward America's rise to worldredemptive heights, to the creation of the New Deal and the victory of liberal democracy over fascism. I do not mean Comedy in the laughable sense; this era contains many of American history's more brutal aspects-lynching, for instance. To call it Comic is to see how even these brutalities, even these descents into hell, are assimilable into a broader narrative of resolution. The liberal international order stands as the reconciliation, the promise of redemption or fulfillment, toward which the Comic arc can bend.

39 The narrative lens falls on vivid personalities and ideologues who, as characters working in, around, and against THE STATE, illuminate a governmental ushering-in of harmony. Labor history and the history of capitalism, which do not lend themselves so tidily to the Comic emplotment, are relegated to the background. The history of populism is chronicled through the lives of Mary Lease and William Jennings Bryan, among others. ${ }^{18}$ Progressivism is given more real estate and more complexity, from Teddy Roosevelt and Woodrow Wilson (presidents and historians both), to legal thinkers, muckraking journalists, and well-intentioned but overzealous engineers of "efficiency." In general, "Populists believed that the system was broken," Lepore writes; "Progressives believed that the government could fix it" (364). From out of the Great Depression, at long last, comes the New Deal, which feels like a happy marriage. Franklin Roosevelt's rise to the presidency marked "a new brand of liberalism that borrowed as much from Bryan's populism as from Wilson's Progressivism” (431).

In this emplotment, American intervention in World War I was a betrayal, a diversion from the nobler course. ${ }^{19}$ The isolationism of the 1920 s reads as the temporary absence or death of the hero before a return or resurrection in World War II and the Atlantic Charter. "The United States, a nation founded in an act of severing, had tied its fate to the fate of the world," Lepore waxes. "A nation that had refused to join the League of Nations had taken the lead in establishing its replacement." The Comic redemption is all the more satisfying after so long a winter. She is also careful to locate, in this period, the origins of the Civil Rights Movement, such as the "scattered sit-ins" organized by Pauli Murray beginning in 1939, as well as the germs of "what would become the UN's

European journal of American studies, 15-2 | 2020 
language of human rights." The American Dream is first dreamt here, too, a phrase coined in James Truslow Adams's Epic of America (1931)-another model for Lepore herself. ${ }^{20}$ The language of the American Dream will "stir leaders of later generations, from Martin Luther King Jr. to Barack Obama," even if noble dreams will become mere dreams in the melancholy irony of Part IV. The book ensures, that is, that these triumphs have a foot in the Comic narrative before Part IV whisks so much away.

41 Comedy does not mean unalloyed happiness; it is a measured achievement of harmony. "In Comedy," White observes, "hope is held out for the temporary triumph of man over his world by the prospect of occasional reconciliations of the forces at play in the social and natural worlds....the condition of society is represented as being purer, saner, and healthier as a result of the conflict among seemingly inalterably opposed elements in the world; these elements are revealed to be, in the long run, harmonizable with one another, unified, at one with themselves and the others." ${ }^{21}$ Balance prevails, in both plot and historical argument. Part III of These Truths balances undoubtedly bad things with redemptive things. World War II brought American concentration camps for Japanese Americans, "and yet the war cultivated new forms of resistance to the racial order." The violence was immeasurable, but "the millions of American sailors and nurses and airmen who fought on all four corners of the globe gained a cosmopolitanism unknown to any previous generation of Americans" (515).

While Part II gestured toward Greek tragedy, Part III invokes the rise of Rome, with overtones of Virgil's Aeneid. (The book boasts a parade of epic epithets-Billy Graham, "broad-shouldered and brylcremed"-and the epilogue will call "the American experiment" "a stirring, terrifying, inspiring, troubling, earth-shaking epic.") (788). The Aeneid tells of the Trojan king Aeneas' escape from the destruction of Troy by Greece, setting off with divine sanction to found Rome. Rome needed such an epic, and the emperor Augustus commissioned one. In These Truths, Reconstruction is something like an American Trojan War. From the Trojan Horse, in this analogy, spring the $\mathrm{Ku}$ Klux Klan and Jim Crow, the revenge of white supremacy, which sends the hero (America) into a period of wandering. Greece founded the epic tradition, and was therefore to be admired, but in Virgil's saga the Greeks have become perfidious villains. ${ }^{22}$ The Aeneid allows Rome both to supersede Greece and to carry on the Homeric tradition, just as These Truths allows the American Century both to supersede an ignoble past and carry on a Constitutional tradition.

43 Lepore's account never descends into sheer boosterism. As in the Aeneid, one feels the author's ambivalence about war and rage, a certain sadness about a warring world even as we read of our own civilization's ascendancy. Virgil is a prototype for all national historians writing from within the nation. The world around the hero descends into brutality, and the hero has no choice but to partake of it. The last chapter of Part III is titled "The Brutality of Modernity," but the brutality that is so grimly revealed, the Holocaust above all, is mostly elsewhere. Even with these melancholy reflections, the emplotment is ultimately Comic: victory in Europe, and an American-led redemption that can, one hopes, make modernity less brutal.

\section{IV.}

44 The honeymoon is brief. Part III closed with a redemptive victory over fascism in Europe; Part IV, THE MACHINE (1946-2016), begins with the atomic bomb. Other 
machines follow: television, the appliances on display at the Kitchen Debate in Moscow, the mainframe computer, the personal computer, the Internet, the gun. The MACHINE is as capacious as the IDEA and is in fact the IDEA's nemesis. War becomes a kind of machinery: while the Comedy of Part III pointed auspiciously toward a welfare state, what happened instead was that "the United States built a national security state" (538). The Vietnam War is a mechanical as much as a moral failure. Lepore points to figures like the MIT social scientist Ithiel de Sola Pool (later author of Technologies of Freedom), who along with other modernization theorists convinced the Kennedy administration to commit more resources to Vietnam. "Convinced that, with enough data, a computer could simulate an entire social and political system, Pool would eventually earn a $\$ 24$ million contract from ARPA for a multiyear research project in Vietnam" (604). Bitterness is the prevailing mood. Often, potential benevolences are reduced to machinery. Science itself is made an instrument of war. Politics is corrupted by amoral "political strategists" and "well-paid political consultants," who are able to succeed because political discourse has been made mechanical by the odious technology of polling. Polls are flashbulbs that reveal everything yet illuminate nothing.

45 Technological change, in Part IV, is now more consequential than other kinds of change-political, geopolitical, moral. This is one reason why, for example, the end of the Cold War does not mark a fundamental historical shift. Americans may have imagined something grand when the Berlin Wall fell, but "they were unable to imagine the revolution in information technology that would resist regulation and undermine efforts to establish a new political order" (695). THE MACHINE thus names an era in which technological change hinders rather than catalyzes political progress. In contrast to the earlier emplotments, technological advance now creates the conditions of political regression, and renders moral or liberal victories fleeting. The causes of and preconditions for Donald Trump's election are shown to be decades old, or older. The vacuum didn't suddenly start sucking in 2016.

46 That mechanical background effectively determines how ideas are expressed and which ideologies prevail. Conservatism prevails because powerful conservatives are more cynical than liberals, and because they capitalize more cleverly on the new mechanics of politics. Liberalism, meanwhile, alienates itself from the people-first through an understandable worry about mass politics in the wake of fascism, eventually by cultural elitism and suspicion of mass culture, and finally by an embrace of a "knowledge economy." (There are exceptions: Dwight Macdonald personified the liberal disdain for mass culture but he also, in a heroic New Yorker article in 1963, made plain "the atrocity of poverty in an age of affluence" [611].)

47 One noble and paradigmatic liberal in this account is the journalist Edward R. Murrow, who, at the close of Part III, was Lepore's lens onto the Holocaust. In the 50s, Murrow maintains a "faith in the American creed, in the triumph of reason over fear, in progress over prophecy." But it is "a shaken faith." Liberals like Murrow are admirable only to the extent that they discern their own predicament; their discernment does not lead to effective action. "Between the unreasoning McCarthy and the coldly calculating computer," Lepore has him wonder, "where was the independent-minded American voter, weighing facts and searching for truth?" (565). Aeneas has to navigate between Scylla and Charybdis; America will crash stupidly into both. 
Part IV is emplotted as a Satire. Its world is not laughable, and there is much to lament, but Satire tends toward wry fatalism rather than catharsis, toward melancholy rather than outrage. The righteous outrage of the Vietnam era is given a place, to be sure. Noam Chomsky, after all, also exposed the machinery of foreign policy and mass media; the key term of Manufacturing Consent (1988) is "manufacturing." ${ }^{23}$ But Satire will render righteousness feckless and pitiable. In 1969, Lepore writes, Chomsky argued that "much of academic life in the United States-the production of knowledge itself-had been suborned for the purpose of waging a grotesque war in which all the courage had been shown by the young, by young soldiers who fought the war, and by young students who protested it" (635). Chomsky's reckoning comes across as necessary then, but it will slide down a slope toward self-defeating shrillness.

49 Leftist critiques of liberal or American mythologies are damned with faint praise and then crunched into the plot of political breakdown. Of revisionist history: "A revolution on the streets produced a revolution in scholarship: a new American past" (635). Yes, it was "long overdue," "but in the context of the war in Vietnam, questioning academic authority and pointing out the biases of experts began to slip into a cynicism about truth itself." This is a straw man. "In some corners of the left, the idea that everything was a lie became a fashionable truth," Lepore laments. "Poststructuralism and postmodernism suffused not only American intellectual life but American politics, too. If everything is politics, and politics is a series of lies, then there is no truth" (636). The reductio ad absurdum is irritating, yet necessary for the broader emplotment: even the dissents that Lepore herself might agree with have to become mechanical versions of themselves-doomed, in effect, to manufacture their own dissent-in order to fit into the grinding erosion of enlightened truth.

50 The Civil Rights Movement is an episode of genuine moral heroism, but it does not endure. Thurgood Marshall is a heroic figure, not least for his abiding faith in the Constitution, but even Marshall must face the fact that successful civil rights litigation depended to an extent on the Cold War. (Everyone gets a simile, and Marshall's is a "thin mustache as pointed as a punctuation mark"-fine, but which punctuation mark?) He ends up both fighting and dancing with that machinery: "The Cold War would keep overshadowing the civil rights movement, and also propelling it forward" (586). Lepore also notes the downsides of court-driven, rights-based desegregation, which "often resulted in black teachers losing their jobs" (581).

51 Martin Luther King, Jr.'s "I Have a Dream" speech, in this emplotment, is a majestic portal in time to an earlier and more dignified plot: "It was as if every bell in every tower in every city and town and village had rung." Another as if: the simile indicates that King was both saint and anachronism. In mechanical reality, people watched the speech on television. Two years later, during the Watts riots of 1965, "King flew to Los Angeles and preached nonviolence; no one really listened." The machinery of Army tanks and helicopters that crushed the riot prefigures the militarized police of our own day. "From the outside, it looked as if rights had been answered with riots, as if the entire project of liberalism were collapsing in on itself" (623).

52 Part IV sometimes foregrounds the direct origins of our own present-Donald Trump first appears as the protégé of the odious Nixon hand Roy Cohn-or it offers prefigurations of our own present. Before Cambridge Analytica, there was Ithiel de Sola Pool's Simulmatics Corporation, a machine for political data first deployed in John F. Kennedy's election. The Cold War-era debate over a nuclear winter-the projected 
environmental impacts of a nuclear war-marks the moment when "conservatives extended their longstanding critique of the 'liberal bias' of the media to science." That episode thus "established the themes and battle lines of the debate over climate change" (682-683). One senses history repeating itself, first as farce and then as bigger farce.

53 Themes and figures from the earlier in the book can now make an ironic return. "Fake news" is as old as fascism. Our era's ideological polarization looks a lot like the polarization of the 1920s. Slaveowners before the Civil War were a "1 percent" that "deployed the rhetoric of states' rights and free trade ..., but in fact they desperately needed and relied on the power of the federal government to defend and extend the institution of slavery" (223). The telegraph prefigures the Internet, though the Internet -a machine of shame, loneliness, and hatred-is so much worse (772).

54 The reader is thus equipped to measure our own era against the past. The sequel does not come off well. There are echoes across time, certainly, but the moral and aesthetic satisfactions of previous emplotments are negated or made unavailable. Satire, in White's terms, "presupposes the ultimate inadequacy" of the other emplotments' visions of the world. It "signals a conviction that the world has grown old." ${ }^{24}$ And so our era is not Tragic, but absurd. At least the Tragic phase could sustain some moral and aesthetic depth; even the grief-in-advance that Lepore finds poetically expressed in the pre-Civil War years is unavailable in our era. Our protagonists are ignoble or stupid rather than grand and grandly flawed. The similes reflect this. In the 1850s, it was "as if" the nation gouged its own eyes out with something like tragic grandeur; the closest our era comes is Lyndon Johnson, passing a tax cut that undermines the Great Society program, "as if he'd cut off one of his own feet" (618).

55 Our era is not a Comedy, but an anti-comedy. Where THE STATE arrived at a harmonious marriage, in the form of the New Deal coalition and the liberal international order, THE MACHINE arrives at hideous mis-marriages. In an earlier era, the Left had achieved some "solidarity across difference" (a good marriage), but it "abandoned" that solidarity "in favor of the meditation on and expression of suffering, a politics of feeling and resentment, of self and sensitivity" (a divorce and a bad remarriage) (701). The Right, meanwhile, marries the worst of mass politics to the worst of plutocracy. "Populism" ends up in an absurd situation of trans-ideological bigamy: "If the Tea Party married populism to originalism, Occupy married populism to socialism" (759). (These -isms are stretched thin, and veer into tendentious false equivalence.)

56 The quests of our era are not Romantic but perverse. Lepore has proper scorn for the "New Democrats" of the Democratic Leadership Council. The Clinton-era Democratic party became "technocratic, meritocratic, and therapeutic." Democrats believed personal computers would pollinate the empowered, therapeutic self, but the computer proved to erode that self-which was an anemic model of selfhood to begin with. Democrats made a fetish of market competition but only ushered in Google, here correctly identified as the largest and most insidious monopoly of all time. "The party stumbled like a drunken man," Lepore writes, "drunk with technological utopianism" (696).

57 Left-liberalism no longer strives for equality but for identity. Such a quest drifts not toward actual fulfillment but toward feckless martyrology. The moral heroes of the post-1945 era remain sources of sentimental inspiration but are useless as pragmatic 
models, despite their indisputable nobility. Identity politics, this account would suggest, will ultimately bring little more than the bitter satisfaction of righteous suffering. And it will lose to a reactionary conservatism that also strives for identity, albeit in a more demonic form.

58 The narrative of Part IV thus threatens to negate everything that has come before, leaving us in a state of dismal irony. Americans "believed they were fighting for the meaning of America, but, really, they were fighting for raw political power" (691). Even the book's aspirational title, These Truths, turns grim: the enlightened Romance of a we that can hold these truths devolves into a farcical we that bickers over incompatible certainties, this truth divorced from that truth. devolves into a Satire. That is what the national history is. Even when it drifts toward bitter lamentation, These Truths has a pleasing rhythm-a rise and a fall, followed by a second rise and a second fall. One can disagree with these emplotments while acknowledging that the narrative architecture, as a narrative architecture, is an achievement of writing and assembly.

61 In the theoretical tradition of White's Metahistory, Romance, Tragedy, Comedy, and Satire are really the only four ur-emplotments in the Western historical imagination, which, if true, would make These Truths that rarest of achievements: the total work of history. A Gesamtgeschichte. A quadruple threat! So perfectly do the parts line up with these emplotments that my paranoid mind did wonder whether Lepore reverseengineered the book from Metahistory, or from Northrop Frye's Anatomy of Criticism, or from some older theory of literary archetypes. That would be its own remarkable feat.

A reverse-engineered history becomes its own circular proof: if those archetypal narratives are, so to speak, the fundamental ingredients of historical consciousness, and if a national history can sustain all four of them, then that national history has, in some mythic or Hegelian sense, fully realized and fully transcended itself. But in These Truths, cunningly, each of the emplotments leaves a deliberate sliver of non-resolution; each of them yearns for closure. That yearning for closure becomes our yearning for closure. The national narrative arrives at the threshold of the reader's experience of the present moment and swells our experience of the present with historic import. This, we feel, is what a national history is for. A reader's absorption into the book effects a mystical absorption into the life of the nation: we are metamorphosed into citizen-readers, keen to rescue the protagonist, who is after all an extension of ourselves.

And yet the spell will break. Stepping back to the book's outermost frame-to the question of whether a people can govern themselves "by reflection and choice" rather than "by accident and force"-you may find yourself breaking the taboo and answering: No. If the national history has run its grand historical cycle, as the book's narrative form would suggest, then is it really possible to revive the enlightened romance? These Truths is both occasioned and constrained by its enormous civic purpose. It cannot entirely give up on "the people," since that would undermine its stated commitment to democracy and popular sovereignty. Since it doubles as an assignable US history textbook, it has to assume that the people are in fact educable. It has no choice but to 
hang from a cliff, though the question and the cliff we're hanged from are ideologically routine.

65 Hope, if there is hope, lies in old poetry and the power of wishful thinking. In 1849, Longfellow began writing a poem called "The Building of the Ship," Lepore writes, "about a beautiful, rough-hewn ship called the Union." He wrote two endings for it. The first was despairing, for "he could imagine nothing but disaster for this worthy vessel." Then Charles Sumner "convinced Longfellow that the Union might yet be saved, and that he ought to write a more hopeful ending to his poem." That's why we have Longfellow's more hopeful ending: "Sail on! Sail on! O Ship of State! / For thee the famished nations wait! / The world seems hanging on thy fate!" (259-260). That's the version FDR memorized and sent to Churchill, who then read it on the radio. These Truths pulls this nugget up through the narrative layers of tragedy and farce and holds it aloft. Longfellow's poem is a miniature for the book itself, in which the first yes-or-no question gives way to a second yes-or-no question, more desperate and sentimental: Can we change the ending?

66 Can history help? Could it have helped? This national history might well reflect a genuine liberal hope that it can. It insists that nations need poetic mystifications, even if we admit that they are, after all, only mystifications. But it is also a self-conscious exercise in the genre of national history-hence its stylized archaism, from the intro ("the Question Stated") to the epilogue ("the Question Answered"), to the bedraggled master metaphors of the storm and the ship of state. "To steer that ship through wind and wave," the epilogue finally concludes, a new generation of Americans "would need to learn an ancient and nearly forgotten art: how to navigate by the stars" (789). The poetry of nationalism on which These Truths ultimately relies itself becomes, well, mechanical.

67 The most obvious problem with the metaphor of the ship of state is that it has little to say about the ocean, nor about the ship poisoning the ocean it sails on-nor, for that matter, about other ships. But this is, by design, a book for the readers still on that ship, which for narrative purposes is the only ship, and if I am honest, I too would prefer that the ship not sink. National histories are mystification machines, but a salutary remystification of the American past is better than nothing.

\section{NOTES}

1. Sacvan Bercovitch, American Jeremiad (Madison: University of Wisconsin Press, 1978). The journalist and historian Frances FitzGerald's reflections, in 1979, on history textbooks in the twentieth century are worth a mention here, for she keenly identified the predicament of "democratic histories" in a bureaucratized age. Any work of civic-minded history will have to place history's "moral burden" somewhere, FitzGerald argued-it is built into the genre. And starting in the 1930s, high school textbooks "developed the habit of displacing [the moral burden] from the real offenders onto the heads of children." The readers, that is, become "the people" on whom the duty of democracy falls. "Their history is a catechism, except that it deals 
with institutions, not individuals. In its flatness and its uncritical conformism, it is a kind of American Socialist realism." Frances FitzGerald, America Revised: History Schoolbooks in the Twentieth Century (Boston: Little, Brown, 1978), 161-162.

2. Mark Twain, The Innocents Abroad; or, The New Pilgrims' Progress (Hartford: American Publishing Company, 1869), 336.

3. Georg Wilhelm Friedrich Hegel, Lectures on the Philosophy of History, trans. John Sibree (London: Henry G. Bohn, 1857), 23.

4. Jill Lepore, These Truths: A History of the United States (New York: W.W. Norton, 2018), xvi, hereafter cited parenthetically.

5. Christine DeLucia, "The Vanishing Indians of These Truths," LA Review of Books (January 10, 2019), https://lareviewofbooks.org/article/the-vanishing-indians-of-these-truths/; Richard White, "New Yorker Nation," Reviews in American History 47 no. 2 (June 2019), 159-167.

6. These events are the focus of Lepore's earlier book, New York Burning: Liberty, Slavery, and Conspiracy in Eighteenth-Century Manhattan (New York: Alfred A. Knopf, 2005).

7. The classic account of Virginia is Edmund S. Morgan, American Slavery, American Freedom: The Ordeal of Colonial Virginia (New York: Norton, 1975).

8. Jane Franklin is the subject of Lepore's earlier book, Book of Ages: The Life and Opinions of Jane Franklin (New York: Alfred A. Knopf, 2013).

9. Hayden White, Metahistory: The Historical Imagination in Nineteenth-Century Europe (Baltimore: Johns Hopkins University Press, 1973), 8-9.

10. Ibid., 161.

11. George Bancroft, Oration Delivered on the Fourth of July, 1826, at Northampton, Massachusetts (Northampton, 1826), 20; Lepore, These Truths, 185.

12. White, Metahistory, 9.

13. Abraham Lincoln, Second Inaugural Address, March 4, 1865, in The Collected Works of Abraham Lincoln (New Brunswick, N.J: Rutgers University Press, 1953), 8:332-333.

14. Karl Marx, "On Events in North America," translated and reprinted in On America and the Civil War, ed. Saul K. Padover, The Karl Marx Library, vol. 2 (New York: McGraw-Hill, 1972), 222. Marx's article originally appeared in the Vienna newspaper, Die Presse (October 12, 1862). White, Metahistory, chapter 8.

15. Roxanne Dunbar-Ortiz, An Indigenous Peoples' History of the United States, Revisioning American History (Boston: Beacon Press, 2014), 5. In both texts, the violent past speaks directly to present, though in different ways. Lepore's epilogue frames the Charlottesville riots of 2017 as a grimly poetic return of the Civil War: "In Charlottesville, Virginia, where a statue of Robert E. Lee had been slated to come down, armed white supremacists marched through the city; one ran down a counter-protester and killed her, as if the Civil War had never ended, she the last of the Union dead." Lepore, These Truths, 787. For Dunbar-Ortiz, it is a straight line from the first permanent English colony of Jamestown, Virginia, founded in 1607, to the Virginia Tech mass shooting 400 years later, in 2007-with no "as if" to shield the present from the past. "The Virginia Tech killings were described... as the worst 'mass killing,' the 'worst massacre,' in US history." DunbarOrtiz notes. "Descendants of massacred Indigenous ancestors took exception to that designation." Central to this narrative of America, and built into the American psyche, is the deep continuity of frontier violence. "The shooter himself was a child of colonial war, the US war in Korea." What Lepore called "unsettling ironies" cannot, in Dunbar-Ortiz's account, be resettled. Dunbar-Ortiz, An Indigenous People's History, 175.

16. Here it is worth mentioning another historical synthesis from 2018 that is aimed at a general reader. Daniel Immerwahr's How to Hide an Empire: A Short History of the Greater United States (New York: Farrar, Strauss \& Giroux, 2018) could stand as a geographical inverse of Lepore's These Truths. is framed not around the fate of IDEAS but of territory. It is a chronicle of the American possessions that are not part of the continental United States. Those possessions include places 
that became states, like Hawaii and Alaska, and places that did not become states but were nevertheless bombed along with Pearl Harbor. It also includes the uninhabited Pacific Islands that were acquired for their agriculturally useful bat guano in the 19th century, and the eight hundred or so military bases that make up the American "pointillist empire" of our own time. Immerwahr's narration tends, revealingly, toward the mode of Satire, befitting a long and often murderous farce.

17. Jill Lepore, This America: The Case for the Nation (New York: Liveright Publishing Corporation, 2019).

18. Starting that history with Mary Lease lets Lepore trace a "female political style" that drove populism, at times heroically. But the style turns toxic in the cynical pseudo-populism of the twentieth century: Richard Nixon's aggrieved and "maudlin" Checkers speech marks one culmination of it. Lepore, These Truths, 331, 563.

19. That betrayal, in Lepore's account, tarnishes figures who are otherwise heroic. W.E.B. Du Bois first enters the narrative as a cool-headed sociologist who turns heroically radical upon witnessing the brutality of lynching: in 1899 he cast aside dry academic inquiry "and decided that 'one could not be a calm, cool and detached scientist while Negroes were lynched, murdered and starved." (370). He was then "brought to heel" in 1916, and drifted with the tide of militarism: "Let us, while this war lasts, forget our special grievances and close our ranks," he wrote, "shoulder to shoulder with our white fellow citizens and the allied nations that are fighting for democracy" (396). But Du Bois will reemerge in the second world war to "put pressure on local and state institutions, and especially on the federal government, to dismantle desegregation" (496).

20. James Truslow Adams, The Epic of America (Boston: Little, Brown, and Company, 1931).

21. White, Metahistory, 9.

22. I have relied on Stanley Lombardo's translation. Virgil, Aeneid, trans. Stanley Lombardo (Indianapolis: Hackett Publishing Company, Inc., 2005).

23. Edward S. Herman and Noam Chomsky, Manufacturing Consent: The Political Economy of the Mass Media (New York: Pantheon Books, 1988).

24. White, Metahistory, 10.

\section{ABSTRACTS}

Traditionally, U.S. history textbooks announce a civic function when aimed at U.S. readers: they exist to read America into the future, to imply a futurity for the American "experiment." But present-day political breakdown has presented deep challenges for the familiar national narrative. Jill Lepore's recent synthesis-These Truths: A History of the United States (2018)-is the most prominent such text to emerge in the wake of the 2016 presidential election. It represents the pinnacle of liberal nationalist historiography and will likely take its place on college syllabi inside and outside the United States. It is also the most substantial attempt in recent years to revive the national history as a serious intellectual genre. This essay takes the form of a narratological interpretation of These Truths. The book is an occasion to consider what national history is and what it is for. 
INDEX

Keywords: historiography, historical revisionism, jeremiad, narratology, national history, textbooks 